Костиков А.П. доктор физико-математических наук, ГВУЗ «ДГПУ»

e-mail: a.kostikov@hotmail.com, ORCID 0000-0002-9041-3209

\title{
ОСОБЕННОСТИ ФОТОФИЗИКИ ТРИПТОФАНА В СОСТАВЕ БЕЛКОВ
}

Показано, что с плоскостью индольной группы триптофана могут взаимодействовать не только атом кислорода карбонильной группы триптофана, но и атомы кислорода других аминокислотных остатков белка. Расстояния для таких взаимодействий не могут превышать $5 \AA$. Обнаружены интересные для дальнейшего изучения пары аминокислотных остатков, равноудаленные от индольной группы и находящиеся с противоположных сторон плоскости кольца на расстояниях от него порядка $4 \AA$.

Ключевые слова: фотофизика, триптофан, белки.

\section{Введение}

После нашей работы [1] в которой был обнаружен эффект светового тушения фосфоресценции триптофана, появились новые экспериментальные данные [2-4], позволяющие понять основные детали механизма фотофизических процессов, ответственных за наблюдаемый эффект. Результаты наших экспериментов позволили предположить, что фотофизические процессы триптофанового остатка белковых молекул могут зависеть от ближайшего окружения этого остатка в молекуле белка. Исследованию такого предположения посвящена данная работа.

\section{Материалы и методы}

Измерения фосфоресценции проводили на фосфороскопической установке, описанной ранее [1], в одинаковых для всех образцов условиях. Растворы помещали в кварцевую трубку с внутренним диаметром 2 мм и замораживали до 77 К. Облучение образцов для генерации люминесценции и фосфоресценции проводили светом в диапазоне длин волн 280-310 нм. Для наблюдения эффекта светового тушения фосфоресценции образец дополнительно облучался светом в диапазоне полосы триплет-триплетного поглощения (400-500нм). Структура изучаемых белков получена из Банка Данных Белков (Protein Data Bank (PDB)). Анализ деталей пространственной структуры исследуемых молекул выполнялся с помощью программного инструмента DeepView (Swiss-PdbViewer), Швейцарский Институт Биоинформатики. 


\section{Результаты и обсуждение}

Ранее нами были выполнены измерения фосфоресценции ряда молекул белков, содержащих триптофан, в условиях, позволяющих наблюдать эффект светового тушения фосфоресценции молекул при дополнительном облучении образца светом в области триплет-триплетного поглощения триптофана (400 - 500 нм) [2-4]. Спектроскопические свойства триптофана определяются его индольной группой, имеющей сопряженную систему $\pi$ - электронов, а также гетероатомом азота, наличие которого снимает квантовомеханические запреты на переходы в ближней УФ области спектра. Наличие в белках триптофанового ароматического аминокислотного остатка позволяет наблюдать для них эффект светового тушения фосфоресценции. В таблице 1 показаны краткие сведения о белках, которые исследовались в данной работе.

Таблица 1. Коды PDB исследованных белков, триптофановые остатки в них и параметры [3] фототушения фосфоресценции $(\delta)$.

\begin{tabular}{|l|c|l|c|}
\hline Белок & Код PDB & Триптофановые остатки белка & $\delta$ \\
\hline Альбумин человека & 1E7B & TRP214 & 0,65 \\
Яичный альбумин & 1OVA & TRP160, TRP194, TRP275 & 0,49 \\
Рибонуклеаза & 1QMT & TRP10, TRP35 & 0,33 \\
\hline
\end{tabular}

При предварительном анализе структуры молекул мы выяснили, что карбонильная группа $>\mathrm{C}=\mathrm{O}$ триптофана в результате вращения вокруг соответствующих одинарных связей С-С может располагаться достаточно близко от индольной группы молекулы. Поскольку за фотофизические свойства индольной группы ответственна сопряженная $\pi$ - электронная система, нас интересовали такие ориентации карбонильной группы, при которых атом кислорода этой группы находится над плоскостью индольной группы. Именно такие ориентации позволяют взаимодействовать электронам $\pi$ - системы индола с электронами карбонильной группы.

Результаты представлены в таблицах 2 - 4. Наши наблюдения касались плоской индольной группы этих фрагментов. Эту группу образуют атомы углерода CE2, CZ2, CH2, CZ3, CE3, CD2, CG, CD1, а также атом азота NE1 (здесь и далее используются стандартные обозначения атомов, принятые в системе PDB). В стандартных случаях указаны расстояния (Ангстрем) от атома кислорода триптофана $(\mathrm{O})$ до одного из атомов углерода $(\mathrm{C})$ или атома азота $(\mathrm{N})$ индольной группы. В некоторых случаях индольная группа сближена с атомом кислорода другого аминокислотного остатка. В таких ситуациях в таблице указан соответствующий аминокислотный остаток и расстояния от его атома кислорода до атомов индольной группы триптофанового остатка. 
Альбумин человека. Результаты измерений для одного из исследованных нами белков, Альбумина человека (1E7B.pdb), представлены в таблице 2. Выбор этого белка обусловлен его относительной простотой и самым высоким, среди измеренных нами, коэффициентом светового тушения фосфоресценции (Табл. 1).

Таблица 2. Расстояния (Ангстрем - А) от атомов индольной группы TRP214 до атома кислорода карбоксильной группы TRP214.

\section{TRP214 - TRP214(O)}

\begin{tabular}{|c|c|c|c|c|c|c|c|c|}
\hline 1 & 2 & 3 & 4 & 5 & 6 & 7 & 8 & 9 \\
\hline O-NE1 & O-CD1 & O-CG & O-CD2 & O-CE3 & O-CZ3 & O-CH2 & O-CZ2 & O-CE2 \\
\hline 4.37 & 3.97 & 3.30 & 3.34 & 3.57 & 4.40 & 4.95 & 4.82 & 4.04 \\
\hline
\end{tabular}

Из таблицы видно, что все 9 атомов, образующих плоскую индольную группу триптофана находятся на расстоянии меньше $5 \AA$ от атома кислорода. Более того, 4 атома углерода индольной группы сближены с атомом кислорода на расстояния меньшие $4 \AA$ А. Такая конфигурация обеспечивает высокую эффективность взаимодействия индольной группы белка с атомом кислорода карбонильной группы и, как следствие, высокую эффективность фотофизических процессов светового тушения фосфоресценции молекулы (Табл. 1).

Яичный альбумин. В этой молекуле имеется три триптофановых остатка - TRP160, TRP194 и TRP275. Кроме того, для каждого из этих остатков его индольная группа может взаимодействовать с атомом кислорода соседних аминокислотных остатков - Тирозина (TYR119) с TRP160, Аланина (ALA343) с TRP194, (Лизина) LYS271 с TRP275. В двух случаях (для TRP160 и TRP275) атомы кислорода соседних аминокислотных остатков находятся с обратной стороны плоскости индольной группы. В Таблице 3 это отмечено знаками $(-)$ перед соответствующими расстояниями.

Из таблицы 3 можно видеть, что для триптофанового аминокислотного остатка TRP160 с двух сторон индольной группы находятся практически на равном удалении атомы кислорода триптофана и тирозина. Отсюда можно было предположить высокую эффективность фотофизических процесов, приводящих к световому тушению фосфоресценции этого белка. Результат наблюдаемого относительно невысокого эффекта, очевидно, требует дальнейших исследований. В данном случае он может маскироваться взаимодействием обоих атомов кислорода на фотофизические процессы в одной и той же индольной группе триптофана. 
Таблица 3. Расстояния от атомов индольных групп TRP160, TRP194 и TRP275 с собственными атомами кислорода и атомами кислорода соседних аминокислотных остатков TYR119, ALA343, LYS271.

TRP160 - TRP160(O)

\begin{tabular}{|c|c|c|c|c|c|c|c|c|}
\hline 1 & 2 & 3 & 4 & 5 & 6 & 7 & 8 & 9 \\
$\mid$ O-NE1 & O-CD1 & O-CG & O-CD2 & O-CE3 & O-CZ3 & O-CH2 & O-CZ2 & O-CE2 \\
\hline 4.36 & 3.77 & 3.37 & 3.81 & 4.34 & 5.27 & 5.73 & 5.34 & 4.42 \\
\hline
\end{tabular}

TRP160 - TYR119(O)

\begin{tabular}{|l|c|c|c|c|c|c|c|c|}
\hline O-NE1 & O-CD1 & O-CG & O-CD2 & O-CE3 & O-CZ3 & O-CH2 & O-CZ2 & O-CE2 \\
\hline-4.92 & -4.39 & -3.50 & -3.62 & -3.64 & -4.54 & -5.31 & -5.34 & -4.50 \\
\hline
\end{tabular}

TRP194 - TRP194(O)

\begin{tabular}{|c|c|c|c|c|c|c|c|c|}
\hline O-NE1 & O-CD1 & O-CG & O-CD2 & O-CE3 & O-CZ3 & O-CH2 & O-CZ2 & O-CE2 \\
\hline 6.60 & 5.38 & 4.58 & 5.61 & 5.95 & 7.33 & 8.23 & 8.03 & 6.76 \\
\hline
\end{tabular}

TRP194 - ALA343(O)

\begin{tabular}{|c|c|c|c|c|c|c|c|c|}
\hline O-NE1 & O-CD1 & O-CG & O-CD2 & O-CE3 & O-CZ3 & O-CH2 & O-CZ2 & O-CE2 \\
\hline 4.33 & 3.35 & 3.77 & 4.92 & 6.00 & 7.12 & 7.31 & 6.45 & 5.18 \\
\hline
\end{tabular}

TRP275 - TRP275(O)

\begin{tabular}{|c|c|c|c|c|c|c|c|c|}
\hline O-NE1 & O-CD1 & O-CG & O-CD2 & O-CE3 & O-CZ3 & O-CH2 & O-CZ2 & O-CE2 \\
\hline 6.55 & 5.22 & 4.58 & 5.79 & 6.31 & 7.67 & 8.50 & 8.15 & 6.85 \\
\hline
\end{tabular}

TRP275 - LYS271(O)

\begin{tabular}{|l|c|c|c|c|c|c|c|c|}
\hline O-NE1 & O-CD1 & O-CG & O-CD2 & O-CE3 & O-CZ3 & O-CH2 & O-CZ2 & O-CE2 \\
\hline-3.94 & -3.54 & -3.18 & -3.36 & -3.90 & -4.73 & -5.08 & -4.73 & -3.87 \\
\hline
\end{tabular}

Для TRP194 с одной стороны индольной группы расположены два атома кислорода, один принадлежит TRP194, а другой ALA343. Из данных, представленных в соответствующем месте таблицы 3 хорошо видно, что атом кислорода существенно удален от плоскости индольной группы (от 5 до $8 \AA$ ). Это означает, что на фотофизические свойства индольной группы этот атом не должен заметно влиять. Возможность взаимодействия TRP194 с атомом кислорода ALA243 сравнима с такой возможностью с участием атома кислорода TRP194. Таким образом можно считать, что фотопроцессами с участием триплетного состояния TRP194 можно пренебречь. 
Интересная ситуация наблюдалась для TRP275. Для этого триптофана вероятность взаимодействия атома кислорода его карбонильной группы с индольной группой должна быть очень малой (расстояние между этими группами от 5 до $8 \AA$ ). Однако атом кислорода соседней аминокислоты LYS271

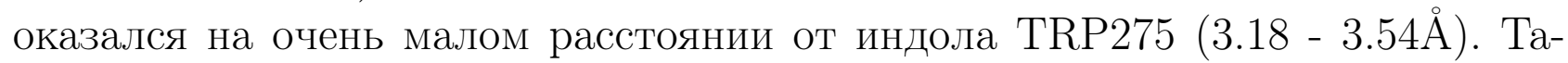
ким образом, в этом случае возможны фотопроцессы с участием триплетного возбужденного состояния, однако они могут носить специфический характер, что требует дополнительных исследований.

Рибонуклеаза. Для каждого из двух триптофановых остатков TRP10 и TRP35 полипептидной цепи этого белка показаны расстояния от соответствующих атома кислорода карбоксильной группы до атомов индольного кольца.

Таблица 4. Расстояния от атомов индольных групп TRP10 и TRP35 до соответствующих атомов кислорода.

\section{TRP10 - TRP10(O)}

\begin{tabular}{|c|c|c|c|c|c|c|c|c|}
\hline 1 & 2 & 3 & 4 & 5 & 6 & 7 & 8 & 9 \\
O-NE1 & O-CD1 & O-CG & O-CD2 & O-CE3 & O-CZ3 & O-CH2 & O-CZ2 & O-CE2 \\
\hline 4.72 & 4.12 & 3.46 & 3.77 & 4.08 & 5.04 & 5.64 & 5.45 & 4.55 \\
\hline
\end{tabular}

\section{TRP35 - TRP35(O)}

\begin{tabular}{|c|c|c|c|c|c|c|c|c|}
\hline O-NE1 & O-CD1 & O-CG & O-CD2 & O-CE3 & O-CZ3 & O-CH2 & O-CZ2 & O-CE2 \\
\hline 4.64 & 3.90 & 3.42 & 3.42 & 4.54 & 5.58 & 6.10 & 5.75 & 4.71 \\
\hline
\end{tabular}

Эти расстояния достаточно малы, что позволяет предположить, что оба этих триптофановых остатка с близкой вероятностью могут давать вклад в эффект светового тушения фосфоресценции белка (см. Табл. 1). Однако, из наших данных (Табл. 1) следует, что ожидаемая высокая эффективность такого эффекта заметно ниже реальной. Выяснение причин этого требует дополнительных исследований.

\section{Выводы}

Результаты наших измерений показали, что с плоскостью индольной группы триптофана могут взаимодействовать не только атом кислорода карбонильной группы триптофана, но и аналогичные составляющие других аминокислотных остатков белка. Расстояния для таких взаимодействий находятся в пределах 3,3 - 5А. Для Яичного альбумина (1OVA.pdb) обнаружены интересные для дальнейшего изучения пары аминокислотных остатков, равноудаленные от индольной группы и находящиеся с противоположных сторон индола на расстояниях от него порядка $4 \AA$. Особый интерес представляет 
изучение фотофизики этого белка для TRP160. Дополнительных исследований требует также заметное различие ожидаемой эффективности светового тушения от измеряемой.

\section{Литература}

1. Львов K.М., Кузнецов С.В., Костиков А.П. Обратимое снижение интенсивности фосфоресценции триптофана при действии света в области триплетного поглощения при 77K. Биофизика. 1993. Т. 38. С. 568-573.

2. Kostikov A.P. Light induced deactivation of tryptophan phosphorescence in proteins. Biophysical Journal. 2003. V. 84. P. 500A.

3. Костиков А.П. Светоиндуцированная дезактивация фосфоресценции триптофана, роль карбонильной группы в механизме этого явления. Збірник наукових праць фізико-математичного факультету ДДПУ. 2018. Вип. 8. С. 65-70.

4. Костиков А.П. Структурные особенности триптофана, влияющие на светоиндуцированную дезактивацию фосфоресценции белков. Збірник наукових праць фізико-математичного факультету ДДПУ. 2019. Вип. 9. C. 52-59.

\section{Kostikov Alexander P.}

Donbas State Pedagogical University, Sloviansk, Ukraine.

\section{Structural particular qualities of tryptophan influencing on the light induced deactivation of proteins phosphorescence.}

The results of our measurements showed that not only the oxygen atom of the tryptophan carbonyl group, but also similar components of other amino acid residues of the protein can interact with the plane of the indole group of tryptophan. Distances for such interactions are in the range $3.3-5 \AA$. For Egg Albumin (1OVA.pdb) pairs of amino acid residues interesting for further study were found that were equidistant from the indole group and located on opposite sides of the indole at distances from it of the order of $4 \AA$. Of particular interest is the study of the photophysics of this protein for TRP160. Additional research also requires a noticeable difference in the expected light quenching efficiency from the measured one.

Keywords: photophysics, tryptophan, protein. 